\title{
Full restoration of marine conditions after the late Messinian Mediterranean Lago-Mare phase in Licodia Eubea and Villafranca Tirrena areas (east Sicily)
}

\author{
Francesco ScIUTo ${ }^{1}$ \\ Angela BALDANZA ${ }^{2}$
}

\begin{abstract}
After the Upper Messinian Mediterranean Lago-Mare phase, at the end of the Messinian salinity crisis, the Mediterranean basin was characterized by a return to normal marine conditions starting with the Lower Pliocene (Zanclean). In this period, remarkably thick layers of calcareous pelitic sediments, very rich in planktonic foraminifers and nannofossils, were widely deposited in the Mediterranean basin. The calcareous pelitic deposits of Sicily (Trubi Formation), as well as in other Mediterranean regions, were deposited conformably on the pre-Pliocene substrate, which is mainly represented by Messinian evaporites or by the post-evaporitic Lago-Mare facies. We have analysed samples taken from the lower portion of the Trubi Formation (Zanclean), just above the Messinian facies, collected from Licodia Eubea and Villafranca Tirrena areas (eastern Sicily). Micropalaentological assemblages consist of benthic and planktonic foraminifers and a typical deep-water ostracod fauna. The microfossil association and the stratigraphy of the Messinian-Pliocene transitional layers, supported by calcareous nannoplankton data, demonstrate not only rapid sea-level rise in this sector of the Mediterranean region, but also that this event, occurred without producing erosional features, unlike at other sites (e.g., Strait of Gibraltar).
\end{abstract}

\section{Key-words:}

- Mediterranean Sea;

- Sicily;

- Zanclean Stage;

- bathyal ostracods;

- bathyal foraminifers;

- Trubi Formation;

- palaeoenvironmental evolution

Citation: ScIUTO F. \& BALDANZA A. (2020).- Full restoration of marine conditions after the late Messinian Mediterranean Lago-Mare phase in Licodia Eubea and Villafranca Tirrena areas (east Sicily).- Carnets Geol., Madrid, vol. 20, no. 6, p. 107-123.

Résumé : Rétablissement total des conditions marines après la phase "Lago Mare" du Messinien supérieur de la Mer Méditerranée dans les régions de Licodia Eubea et Villafranca Tirrena (Sicile orientale).- Après la phase dite "Lago Mare" en Mer Méditerranée, à la fin de la crise de la salinité du Messinien supérieur, le bassin méditerranéen s'est caractérisé par un retour à des conditions marines normales à partir du Pliocène inférieur (Zancléen). Au cours de cette période, des accumulations remarquablement épaisses de sédiments pélitiques calcaires très riches en foraminifères planctoniques et nannofossiles se sont déposées dans le bassin méditerranéen. En Sicile, ces sédiments pélitiques calcaires sont connus à l'affleurement sous l'appellation de Formation de Trubi. Comme dans d'autres régions méditerranéennes, ils ont été déposés en concordance sur le substrat préPliocène, qui est essentiellement représenté par les évaporites messiniennes ou par des sédiments post-évaporites à faciès "Lago Mare". Pour cette étude, nous avons analysé des échantillons récoltés dans les secteurs de Licodia Eubea et Villafranca Tirrena (Sicile orientale) à la base de la Formation de Trubi (Zancléen), immédiatement au-dessus du faciès messinien. Les résidus de lavages sont caractérisés par des associations micropaléntologiques de foraminifères, benthiques et planctoniques, et d'ostracodes typiques d'eaux profondes. Les caractéristiques de ces associations de microfossiles et l'observation stratigraphique des couches de la transition Messinien-Pliocène témoignent d'une élévation rapide du niveau de la mer dans ce secteur de la région paléoméditerranéenne; en outre, elles sembleraient démontrer qu'ici, contrairement à ce qui a été observé sur d'autres secteurs (e.g., détroit de Gibraltar), cet événement serait survenu sans y produire de traces tangibles d'érosion.

\footnotetext{
${ }^{1}$ Department of Biological, Geological and Environmental Sciences, Corso Italia 57, 95029 Catania (Italy); Conisma, Roma (Italy) fsciuto@unict.it

2 Department of Physics and Geology, University of Perugia, Via Pascoli, 06123 Perugia (Italy) angela.baldanza@unipg.it
}

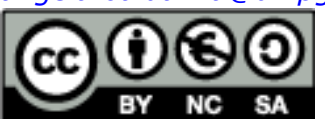

Published online in final form (pdf) on March 17, 2020

[Editor: Bruno GRANIER; language editors: Stephen CAREY and Bruno FERRÉ] 


\section{Mots-clefs :}

- Mer Méditerranée ;

- Sicile ;

- Zancléen ;

- ostracodes bathyaux ;

- foraminifères bathyaux ;

- Formation de Trubi ;

- évolution du paléoenvironnement

\section{Introduction}

During the Messinian Salinity Crisis (Hsü et al., 1973), which lasted for about 640 kyr (KRIJGSMAN et al., 1999; ROVERI et al., 2014), various layers of evaporites, ranging in thickness from a few metres to hundred of metres, were deposited on the bottom of euxinic basins in a large part of the palaeo-Mediterranean area (RoucHY \& CARUSO, 2006).

During the Messinian post-evaporitic phase, several parts of the Mediterranean Basin emerged and were affected by strong subaerial erosion, chemical dissolution of evaporitic rocks and, in the broad shallow basin, deposition of terrigenous sediments containing brackish or freshwater faunas mostly of Paratethysian affinity (ORSZAG-SPERBER et al., 2000; ROUCHY et al., 2007; GLIOZZI et al., 2007; GUerRA-MerCHÁn et al., 2010; SCIUTO et al., 2018; TeMANi et al., 2018). This sedimentary facies, called "Lago-Mare" sensu RugGIeRI (1967), crops out discontinuously but widely throughout the Mediterranean Basin (e.g., CITA et al., 1978; OrSzAG-Sperber et al., 2000; ROUChy \& Caruso, 2006).

In the Zanclean Age (early Pliocene), in several areas of the Mediterranean Basin, thick layers of sediment consisting of white pelitic limestone rich in planktonic foraminifers (Trubi Formation) (CITA, 1975; CITA et al., 1990) and other correlated sedimentary facies (GUeRRA-MERCHÁn et al., 2010; LANCIS et al., 2015) were deposited conformably on either Messinian evaporitic or post-evaporitic facies (BARRA et al., 1998; Grossi et al., 2015; Gennari et al., 2008). These sediments show that, during the Zanclean, the Mediterranean basin returned to fully marine conditions because it was filled by a huge mass of water from the Atlantic Ocean (Zanclean flood) (CITA, 1975; CitA et al., 1990; CITA \& RYAN, 1973; BenSON, 1973; ROUCHY et al., 2001; GARCIA-CASTELLANOs et al., 2009; KRIJGSMAN et al., 2018).

The present paper focuses on the marine ostracods, calcareous nannofossils and foraminifers collected from Zanclean stratigraphic levels cropping out above the evaporitic or post-evaporitic facies in two localities of eastern Sicily, Licodia Eubea and Villafranca Tirrena.

We aim simultaneously to a) analyse taxonomically and stratigraphically the most useful ostracod and foraminifers species found in the collected samples, and b) to reconstruct the palaeoenvironment in two sectors of the Mediterranean Basin for a period when, after the Messinian desiccation, normal-marine conditions were restored.
The Zanclean stratigraphic interval in the Mediterranean basin has been intensively analysed, both in outcrop and in cores, especially from biostratigraphic and palaeoecological perspective, at Capo Rossello (CitA \& GARTNer, 1973; CITA, 1975; LANGereis \& Hilgen, 1991) and Eraclea Minoa (Couvering et al., 2000) along the southern Sicilian coast; at Buonfornello along the Tyrrhenian Sicilian coast (COUvering et al., 2000); in some localities of southern Italy, e.g., Capo Spartivento, Singa and Roccella (CHANnel et al., 1988; CouVERING et al., 2000) and broadly across the Mediterranean Basin (CITA \& RYAN, 1973; CITA, 1975; HASEgAwa et al., 1990; SpROVIERI \& HASEgawa, 1990; BARRA et al., 1998; SPEZZAFERRI et al., 1998; Couvering et al., 2000; GenNARI et al., 2008; Trenkwalder et al., 2008; Di Stefano \& StURiale, 2010; Cipollari et al., 2013).

While considerable attention has been given to upper Messinian Lago-Mare ostracods (ScIUTo et al., 2018, and references therein) much remains to be reported on Zanclean ostracods. Our study adds significantly to those of TRENKWALDER et al. (2008) on the Tertiary Piedmont Basin, Cipollari et al., 2013, on the Adana Basin (southern Turkey), and BENSON and RUGGIERI on single species or on particular groups of species (e.g., RUGGIERI, 1953, 1992; BENSON, 1973; BARRA et al., 1998).

\section{Geological setting}

The early Pliocene deposits sampled for this study belong to two different palaeogeographic contexts: the Villafranca Tirrena Basin (to the North) and the northwestern border of the Hyblean Plateau (to the South) (Fig. 1). In both cases the analysed sections have been attributed to the basal Zanclean, ostracod biozones CNPL1 Zone sensu BACKMAN et al. (2012) or MNN 12 biozone sensu MARTINI (1971) (SCIUTO et al., 2018).

The Villafranca Tirrena Basin, situated in NE Sicily on the Tyrrhenian coast (Figs. 1-2), is structurally part of the Apennine-Maghrebian Chain ("Aspromonte Unit" auct.). It is characterised by a metamorphic basement covered unconformably by Miocene and Plio-Pleistocene deposits with extremely variable thickness (from a few to tens of meters), frequent facies changes, stratigraphic gaps and unconformities (LENTINI et al., 1987). The sedimentary sequence starts with early-middle Miocene polygenic conglomerates passing laterally and upward to grey clayey marls with fine sand. Overlying these facies is the Messinian sequence, consisting of evaporitic carbonates (Calcare di Base auct.), calcareous breccias and 


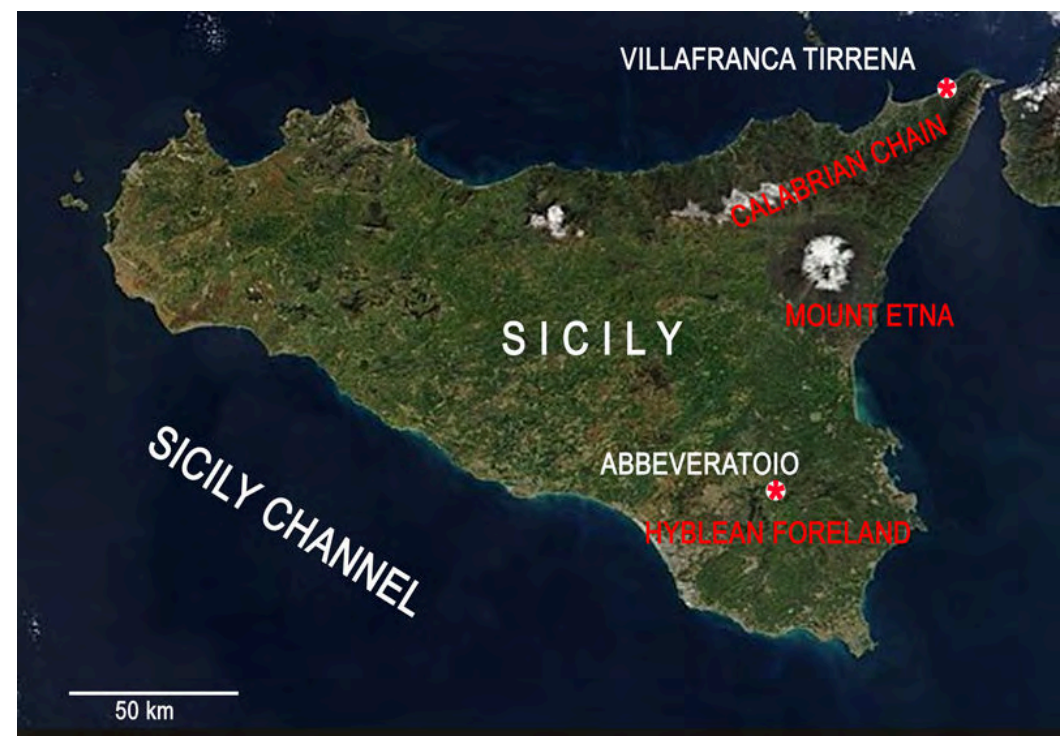

Figure 1: Location of the Villafranca Tirrena and Abbeveratoio sections.

gypsum. During the post-evaporitic phase, medium and coarse sands and breccias, called "Arenazzolo" were deposited (e.g., MotTURA, 1871; Ogniben, 1957; Sciuto et al., 2018). This deposit, where only the ostracod genera Tyrrhenocythere and Cyprideis were found, represents the LagoMare facies deposited in hyposaline or lacustrinefluvial environments at the end of the Messinian (ScIUTo et al., 2018). The sequence continues with the early Pliocene (Zanclean) Trubi Formation, evolving upwards to Pleistocene marls and sands.

The second area (Figs. 1-2) is a part of the Hyblean foreland, a predominantly calcareous plateau that occupies the SE sector of Sicily. The outcropping stratigraphic sequence, consisting mainly of carbonate sediments, with intercalated subaerial and submarine volcanic products, represents semi-continuous deposition from the Early Cretaceous to the Pleistocene (LENTINI et al., 1987).

Also in the Hyblean sector, a series of deposits signifying the Salinity Crisis was formed during the Messinian Age. These include confined and discontinuous siliceous laminated sediments (Tripoli Formation), evaporitic limestones (Calcare di Base) and gypsum, which were deposited in semi-closed synsedimentary tectonic basins, at a depth of 150-200 metres (PEDLEY \& GRASSO, 1992).

Conformable post-evaporitic upper Messinian deposits followed. They consist of carbonate and gypseous breccias, marls, sands and silts locally containing oligohaline to freshwater faunas (Lago-Mare Facies). The beds are known as the "Congeria strata" where they are made up of marls containing oligohaline mollusc faunas and ostracods (Di Geronimo et al., 1989; PeDLEY \& GRASSO, 1992; ScIUTO et al., 2018) or as "Arenazzolo" where consisting of reddish arkoses containing brackish to freshwater ostracods (BONADUCE \& SgARRELla, 1999; Roveri et al., 2008; Sciuto et al., 2018). These deposits belong to the upper part of the Loxoconcha muelleri Zone sensu
GRossi et al., 2011 (lower post-evaporitic phase of the Messinian stage) due to the co-occurrence of Cyprideis agrigentina DECIMA, 1964, Loxoconcha muelleri (MÉHES, 1908), Loxoconcha eichwaldi LIVENTAL, 1929, and Tyrrhenocythere pontica (LIVENTAL) in Agalarova et al., 1961 (Sciuto et al., 2018).

The upper Messinian is overlain conformably by remarkably thick layers of lower Pliocene (Zanclean) white chalks, very rich in planktonic foraminifers and calcareous nannofossils (Trubi Formation), which represent the restoration of fully marine conditions. In the Licodia Eubea area, Pleistocene calcarenites and marls can be found at the top.

\section{Material and methods}

In the Villafranca Tirrena Basin, the chosen section, named Villafranca Tirrena (VT) (Figs. 12 ), crop out on the southern slope of Guardiola hill along the Galvaruso-Fondaco road $\left(38^{\circ} 14^{\prime}\right.$ $02.42^{\prime \prime} \mathrm{N}$; $15^{\circ} 26^{\prime} 14.11^{\prime \prime} \mathrm{E}$; height 43 meters a.s.l.). In this locality, the lower Pliocene Trubi Formation (Fig. 2), consisting of white marl alternating with limestone, conformably overlies the upper Messinian post-evaporitic Lago-Mare facies represented by terrigenous medium- and coarsegrained sands and breccias (Arenazzolo) with ostracods belonging to the genus Cyprideis (ScIuTо et al., 2018). Eight samples were taken from the base of the Trubi Formation (Fig. 2).

In the Hyblean foreland, the Abbeveratoio (LI) section (Figs. 1-2) is located a few dozen metres south of the village of Licodia Eubea (37\%09' $20.11^{\prime \prime} \mathrm{N}$; $14^{\circ} 42^{\prime} 33.81^{\prime \prime} \mathrm{E}$; height 554 meters a.s.l.). The section starts with three metres of well stratified Messinian gypsum conformably overlain by a $50-\mathrm{cm}$-thick layer of post-evaporitic Lago-Mare facies represented by reddish sands and silty sands (Arenazzolo) with ostracods belonging to the genera Cyprideis and Tyrrhenocythere (ScIUTO et al., 2018). The lower Pliocene Trubi Formation is conformable and consists of 


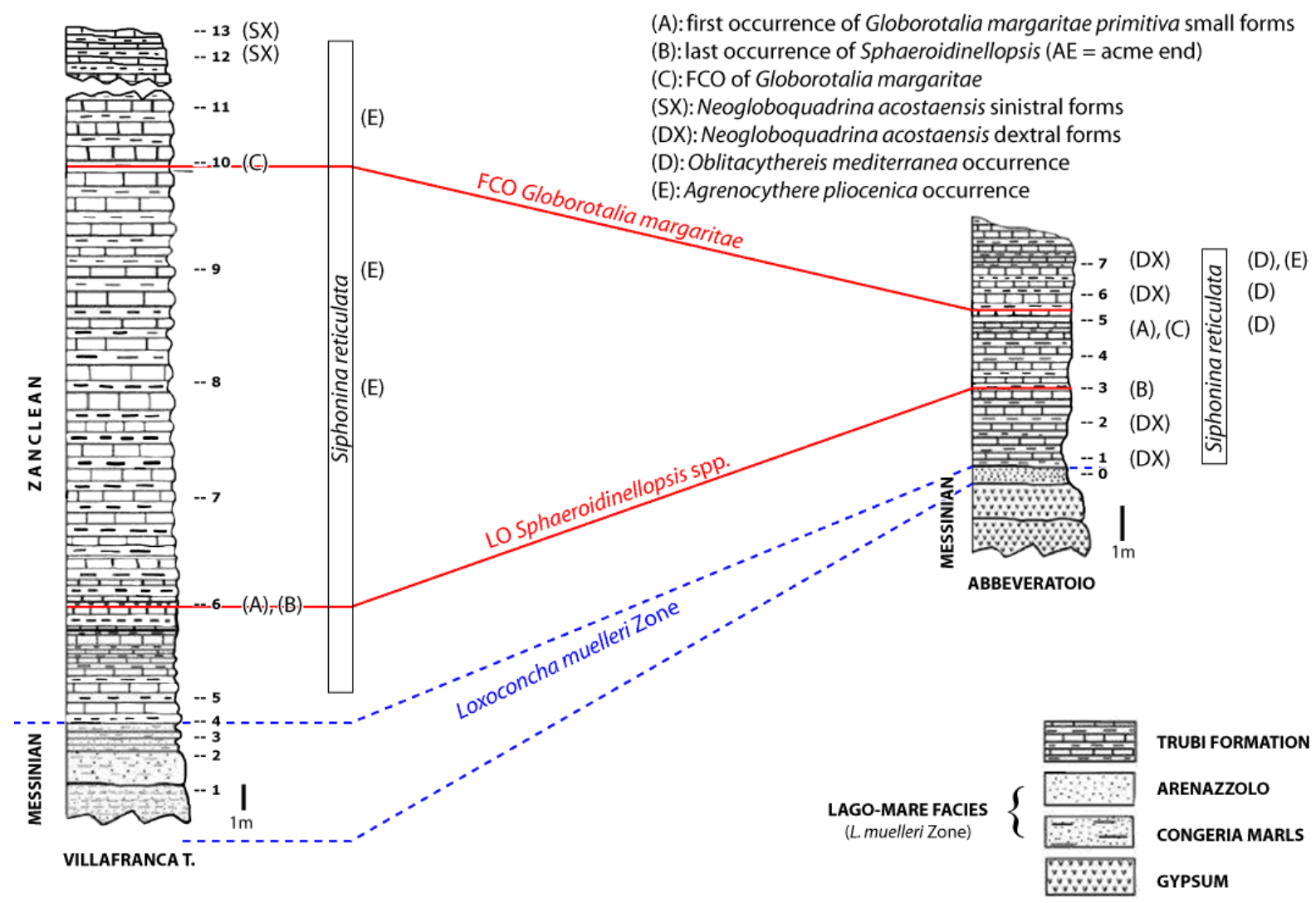

Figure 2: Villafranca and Abbeveratoio stratigraphic logs. Correlations and main biostratigraphic events.

predominantly white marls and marly limestones (Trubi Formation), $7 \mathrm{~m}$ thick and containing rare specimens of Neopycnodonte navicularis (BRoc$\mathrm{CHI}, 1814$ ) and common trace fossils attributable to Zoophycos spp. Seven samples were taken from this formation (Fig. 2).

Ostracod and benthic and planktonic foraminiferal assemblages were extracted for micropalaeontological analysis. From each sample, $250 \mathrm{~g}$ of sediment was washed using diluted hydrogen peroxide for disaggregation. The residues were sieved through standard sieves $(63 / 125 / 250 / 500$ $\mu \mathrm{m})$. All ostracods in the $<250 \mu \mathrm{m}$ fraction of each sample were picked and subjected to careful taxonomic examination. From the $>125 \mu \mathrm{m}$ fraction $0.2 \mathrm{~g} /$ sample was picked and then a quarter of the sample was analysed if necessary for foraminifers. The ostracod specimens were examined and measured under a stereomicroscope and photographed in the LMU Tescan Vega II Scanning Electron Microscope of the Electronic Microscopy Laboratory of the Earth Science Section (University of Catania). The specimens are housed in the Palaeontological Museum of Catania University. Micrographs of foraminiferal specimens were taken by a scanning electron microscope (GEOL /EO Instrument JCM-6000), at the Center for Climate Change and Biodiversity in Lakes and Wetlands of Arpa Umbria, Perugia (Italy), with the collaboration of Dr Rosalba Padula, and the specimens are deposited in the Department of Physics and Geology, University of Perugia (Italy).

\section{Results}

\subsection{Ostracods}

A total of 19 species belonging to 18 genera has been found in Abbeveratoio section whereas 17 species belonging to 12 genera are recognised in the Villafranca Tirrena section (Table I; Plate 1). The species common to both sections, though with marked differences in abundance and distribution are: Agrenocythere pliocenica (SEGUENZA, 1880), Costa tricostata pliocenica RUGGIERI, 1992, Bythocypris antoniettae ScIUTO, 2012, Bythocypris obtusata (SARS, 1866), Cytherella sp. 1 and Henryhowella ex group $H$. profunda BonADUCE et al., 1999 (sensu ScIUTO, 2014a), Henryhowella ex group H. hirta (COSTA, 1853) (sensu ScIUTO, 2014a) and Bairdia conformis (TERQUem, 1878).

The species that are particularly abundant and widespread in the lower part of the Abbeveratoio section (Fig. 2; Table I) are: Henryhowella ex group H. profunda BonADUCE et al., 1999 (sensu SCIUTO, 2014a), Cytherella sp. 1., Cytherella russoi Sissingh, 1972, C. tricostata pliocenica RUGGIERI, 1992, Henryhowella ex group H. hirta (CosTA, 1853) (sensu ScIUTO, 2014a) and Agrenocythere pliocenica (SEGUENZA, 1880). Less abundant and widespread are Oblitacythereis mediterranea BENSON, 1977, Bythocypris obtusata (SARS, 1866) and Acanthocythereis colinii ScIUTO, 2014b. Poorly represented and of limited distribution are Bairdia conformis (TERQUEM, 1878), Bairdoppilata sp., Buntonia dertonensis RUGGIERI, 1954, Buntonia sublatissima (NeVIanI, 1906), Bythocypris an- 
toniettae ScIUTO, 2012, Ruggieria tetraptera palpebralis RUGGIERI, 1960, Pseudopsammocythere sp., and Krithe cf. inqua ABATE et al., 1993.

The ostracods of Villafranca Tirrena section are relatively rare and occur with few specimens in individual samples. Nevertheless, it is only here that species of Parakrithe as well as Buntonia subulata subulata RUgGIERI, 1954, Bythocypris bosquetiana (BRADY, 1866), Cytheropteron eleonorae ScIUTO, 2012, Cytheropteron pinarense (BoLD, 1946) and Cytherella sp. occur.

Species of Krithe are a particular feature of this section, in some cases in high abundance, with the most abundant being Krite compressa (Seguenza, 1880).

\subsection{FORAMINIFERS}

The assemblages of the two sections are similar with 49 species identified at Abbeveratoio and 44 species at Villafranca Tirrena (Table I; Plate 2 ). Benthonic foraminifers dominate the assemblages with a peak of 31 species at Abbeveratoio section and 29 species at Villafranca Tirrena. The planktonic foraminifers are represented by 15 and 18 species respectively in Villafranca Tirrena and Abbeveratoio sections.

In the Villafranca Tirrena section the Globigerina bulloides group (G. bulloides, G. praebulloides and $G$. falconensis) dominates the assemblages from the base to the top (sample VT 12), with high to very high frequencies. Species belonging to this group are cold-water eutrophic and thriving the Intermediate Water (IW). A slight decrease of $G$. bulloides abundance (to common) occurs in samples VT 7, VT 8 and VT 10 whereas G. falconensis, which is rare in the four basal samples, then becomes abundant.

The abundances of the warm-water oligotrophic species, Globigerinoides ruber and G. sacculifer, show trends opposite to that of the G. bulloides group.

The surficial cold-water eutrophic form, Turborotalita quinqueloba, is frequent or common in samples VT 5 and VT 6 and becomes abundant from VT 9 to the top of the section. The neogloboquadrinids, represented by Neogloboquadrina acostaensis (sinistral coiled forms), are variously rare or frequent in the basal samples and then become common to abundant from VT 10 to the top. Orbulina universa is always very abundant and dominates all sample assemblages. Sphaeroidinellopsis occurs only in the basal samples (VT 5 and VT 6), where it is rare, and then disappears.

Globorotalia margaritae, referred to G. margaritae primitiva CITA, 1973, is found throughout the section, where it varies from rare in the basal sample, VT 6, to common or abundant in VT 10. The large taxa, G. margaritae and G. margaritae evoluta (Plate 2), are common in VT 10 and increase to abundant at the top. At Abbeveratoio, the small species, G. margaritae primitiva, occurs only in sample LI 5, where it is rare, at the first appearance of $G$. margaritae large specimens. $G$. margaritae become common in LI 6 and after abundant in LI 7.

It is important to note that in section VT Globorotalia menardii and G. menardii neoflexuosa, including some aberrant specimens are common to abundant in samples from VT 10 to the top. G. puncticulata is abundant in the uppermost samples of VT whereas at Abbeveratoio it is rare and occurs only at the top (sample LI 7).

At Abbeveratoio Globigerina bulloides, G. falconensis and $G$. praebulloides are variable in frequency, and fluctuate from very abundant ( $G$. bulloides) in the basal samples, LI 1 and LI 2, to rare and/or common in samples LI 3-LI 7. The genus Globigerinoides (here represented by $G$. obliquus, $G$. ruber and $G$. sacculifer) is variably frequent with $G$. obliquus abundant to common in LI 1 and LI 2, rare in LI 3 and LI 4, and abundant from LI 5 to the top. G. ruber and G. sacculifer are mainly common with a slight decrease in samples LI 4 and LI 7.

Genus Orbulina dominates all samples, and is abundant to very abundant. The neogloboquadrinids are represented by rare Neogloboquadrina incompta and frequent to common $N$. acostaensis (dextrally coiled forms) in samples LI 1 and LI 2, and become rare from LI 5 to the top. Sphaeroidinellopsis species are commonly in the basal samples, become rare in LI 3, and are absent from overlying samples.

At Abbeveratoio, the epifaunal species Planulina ariminensis and the epifaunal and detritivore species Lenticulina orbicularis are consistently abundant to very abundant whereas Cibicidoides pseudoungerianus is common in the basal samples LI 1 and LI 2, becomes rare in LI 3 and LI 4, and sharply increases to being abundant in LI 5, where it is accompanied by abundant $C$. ungerianus and Cibicides cicatricosus. In the samples LI 6 and LI 7, all three species of Cibicidoides are rare.

In the case of infaunal species, the shallow-infaunal Siphonina reticulata ranges from common to abundant in all samples while Bulimina aculeata, B. marginata, Uvigerina peregrina and U. pygmaea are common to abundant in samples LI 5 to LI 7.

At Villafranca Tirrena species that occur in all samples are the epifaunal Lenticulina orbicularis and Planulina ariminensis and the shallow infaunal Siphonina reticulata.

The epifaunal species Cibicidoides pseudoungerianus is common only in the basal sample and then decreases markedly before becoming frequent in samples VT 10, VT 12 and VT 13. Planularia cassis, which prefers cold bottom waters, is common to frequent in the basal samples, becomes abundant in VT 9, and then decreases to common at the top of section.

The species Marginulinopsis costata, which prefers soft substrates enriched in organic matter (BALDANZA et al., 2018), is common only in sample VT 11 whereas Uvigerina pygmaea and $U$. peregrina are common in samples VT 10 and VT 11. 
Table I: Ostracods and foraminifers species found in Villafranca (VT) and Abbeveratoio (LI) sections. (X: 1 specimens. R: from 2 to 9 specimens. F: from 10 to 29 specimens. C: from 30 to 49 specimens. A: over 50 specimens. AA: over 100 specimens).

\section{Ostracods}

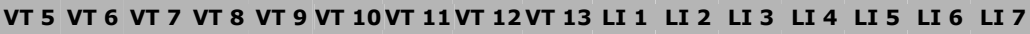

Acanthocythereis colini ScIUTO, 2014

Agrenocythere pliocenica (SEGUENZA, 1880) Argilloecia spp.

Bairdia conformis (TERQUEM, 1878) Bairdoppilata sp.

Buntonia dertonensis RUGGIERI, 1954

Buntonia sublatissima (NEVIANI, 1906)

Buntonia subulata subulata RUGGIeRI, 1954

Bythocypris antoniettae ScIUTO, 2012

Bythocypris bosquetiana (BRADY, 1866)

Bythocypris obtusata (SARS, 1866) Bythocypris sp. 1 tata pliocenica RUGGIERI, 1992 Cytherella sp. 1

Cytherella sp. 2

Cytheropteron eleonorae ScIUTO, 2012

Cytheropteron pinarense (BOLD, 1946)

Cytherella russoi SISsingH, 1972

Cytherella sp. 3

Echinocythereis sp.

Henryhowella ex $H$. profunda BONADUCE et al., 1999 group Henryhowella ex $\mathrm{H}$. hirta

(COSTA, 1853) group

Krithe iniqua BARRA et al., 1993

$\mathrm{x} \quad \mathrm{x}$

$\mathrm{X}$

$x$

$x$

$x$

$x+x$

954

)

\begin{tabular}{|c|c|c|c|c|c|c|}
\hline & & & & & $x$ & \\
\hline & & & $x$ & & & \\
\hline & $x$ & & & & & $x$ \\
\hline & & $x$ & & & & \\
\hline$x$ & & $x$ & & $x$ & $x$ & $x$ \\
\hline
\end{tabular}

$\begin{array}{lllllllllllll}x & & x & x & x & x & & x & & \\ & x & x & x & x & x & x & x & x & R \\ x & x & & & & & & & & & \\ & & x & & & & & & & & \end{array}$

$x$

rithe cf. K. iniqua BARRA et al., 1993

Krithe compressa (SEGUENZA, 1880)

Krithe perpulchra ABATE et al., 1993 Krithe spp.

Oblitacythereis mediterranea BENSON, 1977

Parakrithe sp. 1

Parakriyhe sp. 2

Pseudopsammocythere sp.

(x)



$x$

X

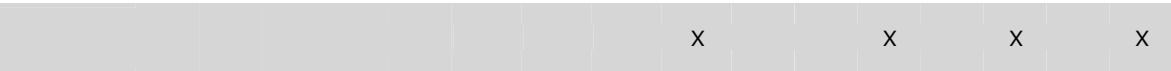

$x \quad x \quad x$

$x \quad x \quad R \quad x \quad x$

$\mathrm{x} x$

$\mathrm{X}$

$x \quad x$

Ruggieria tetraptera palpebralis RUGGIERI, 1960

\begin{tabular}{|c|c|c|c|c|c|c|c|c|c|c|c|c|c|c|c|c|}
\hline Planktonic foraminifera & VT 5 & VT 6 & VT 7 & VT 8 & VT $9 \mathrm{~V}$ & IT 10V & /T 11 & VT 12 & VT 13 & LI 1 & LI 2 & LI 3 & LI 4 & LI 5 & LI 6 & LI 7 \\
\hline Globigerina bulloides (ORBIGNY, 1826) & AA & AA & $\mathrm{F}$ & c & AA & A & A & c & AA & AA & AA & $\mathrm{R}$ & $\mathrm{R}$ & c & c & $\mathrm{R}$ \\
\hline Globigerina falconensis BLow, 1959 & & $\mathrm{R}$ & $\mathrm{R}$ & $\mathrm{R}$ & A & C & C & C & C & & C & $\mathrm{R}$ & $\mathrm{R}$ & & & \\
\hline Globigerina praebulloides BLow, 1959 & A & AA & AA & A & AA & c & A & c & c & $\mathrm{R}$ & c & c & c & A & c & $\mathrm{R}$ \\
\hline Globigerina siphonifera ORBIGNY, 1839 & $\mathrm{~F}$ & $\mathrm{~F}$ & $\mathrm{~F}$ & c & $\mathrm{R}$ & $\mathrm{R}$ & $\mathrm{R}$ & $\mathrm{R}$ & $\mathrm{R}$ & & & & & & & \\
\hline Globigerinella obesa BoLLI, 1957) & A & AA & c & c & A & c & c & $\mathrm{R}$ & $\mathrm{R}$ & & & & & & & \\
\hline Globigerinoides obliquus (BoLLI, 1957) & & & & & & & & & & A & C & $\mathrm{R}$ & $\mathrm{R}$ & C & C & A \\
\hline Globigerinoides ruber (ORBIGNY, 1839) & $\mathrm{F}$ & c & $\mathrm{F}$ & A & AA & AA & A & A & A & c & c & c & $\mathrm{R}$ & c & c & c \\
\hline Globigerinoides sacculifer (BRADY, 1877) & $\mathrm{F}$ & C & $\mathrm{F}$ & A & A & AA & A & A & C/A & c & c & c & $\mathrm{R}$ & c & c & $\mathrm{F}$ \\
\hline $\begin{array}{l}\text { Globorotalia crassaformis } \\
\text { (GALLOWAY \& WISSLER, 1927) }\end{array}$ & & & & & & & & & & & $\mathrm{R}$ & $\mathrm{R}$ & & c & $\mathrm{F}$ & A \\
\hline Globorotalia margaritae primitiva CITA, 1973 & & $x$ & $x$ & $\mathrm{R}$ & $\mathrm{R}$ & A & & & & & & & & $\mathrm{R}$ & & \\
\hline Globorotalia margaritae BOLLI \& BERMUDEZ, 1965 & & & & & & c & A & & $\mathrm{R}$ & & & & & $\mathrm{R}$ & c & A \\
\hline Globorotalia menardii (ORBIGNY, 1826) & & $\mathrm{R}$ & & & & c & A & $\mathrm{R}$ & c & & & & & & $\mathrm{R}$ & \\
\hline $\begin{array}{c}\text { Globorotalia menardii neoflexuosa } \\
\text { SRINIVASAN, } 1974\end{array}$ & & & & & & c & c & & c & & & & & & $\mathrm{R}$ & \\
\hline $\begin{array}{l}\text { Globorotalia puncticulata } \\
\text { (ORBIGNY in DESHAYES, 1832) }\end{array}$ & & & & & & & & A & c & & & & & & & $\mathrm{R}$ \\
\hline Neogloboquadrina acostaensis (BLow, 1959) & $\mathrm{R}$ & $\mathrm{F}$ & & $\mathrm{F}$ & $\mathrm{R}$ & c & $\mathrm{R}$ & $A(s)$ & $\mathrm{C}(\mathrm{s})$ & $F(d)$ & $C(d)$ & & & $R(d)$ & $R(d)$ & $R(d)$ \\
\hline Orbulina universa ORBIGNY, 1839 & AA & AA & AA & AA & AA & AA & AA & AA & AA & A & AA & AA & AA & AA & A & AA \\
\hline Orbulina suturalis BRÖNNIMANN, 1951 & & & & & & & & & & c & A & A & $\mathrm{F}$ & $\mathrm{R}$ & c & c \\
\hline Sphaeroidinellopsis spp. & & $\mathrm{x}$ & $\mathrm{x}$ & & & & & & & c & $\mathrm{F}$ & $\mathrm{R}$ & & & & \\
\hline Turborotalita quinqueloba (NATLAND, 1 & C & A & $\mathrm{F}$ & C & A & A & C & C & $\mathrm{R}$ & & & & & & & \\
\hline
\end{tabular}


Benthic foraminifera

VT 5 VT 6 VT 7 VT 8 VT 9 VT 10VT 11VT 12VT 13 LI 1 LI 2 LI 3 LI 4 LI 5 LI 6 LI 7

Bulimina aculeata ORBIGNY, 1826

$X \quad R \quad R \quad R$

Bulimina marginata ORBIGNY, 1826

Cibicides cicatricosus (SCHWAGER, 1866)

Cibicidoides pseudoungerianus (CUSHMAN, 1922)

Cibicidoides ungerianus (ORBIGNY, 1846)

Florilous boueanum (ORBIGNY, 1846) Cibicidoides wuellersdorphii

(SCHWAGER, 1866)

Gyroidina altiformis

R.E. STEWART \& K.C. STEWART, 1930

Heterolepa floridana CUSHMAN, 1918

Hoeglundina elegans (ORBIGNY, 1826)

Laevidentalina filiformis (ORBIGNY, 1826)

Lagena striata (ORBIGNY, 1839)

Lenticulina orbicularis (ORBIGNY, 1826)

Lenticulina calcar (LINNAEUS, 1758)

Lobatula lobatula (WALKER \& JACOB, 1798)

Marginulinopsis costata (BATSCH, 1791)

Marginulina hirsuta ORBIGNY, 1826

Melonis padanum PeRCONIG, 1952

Mucronina compressa (CostA, 1855)

Mucronina monachanta (REUSS, 1850)

Planularia cassis (FICHTEL \& MoLL, 1798)

Planulina ariminensis ORBIGNY, 1826

Siphonina reticulata (CZJZEK, 1848)

Uvigerina peregrina CUSHMAN, 1923

Uvigerina pygmaea ORBIGNY, 1826

Vaginulinopsis/Vaginulina

Vulvulina pennatula (BATSCH, 1791)

\subsection{NANNOFOSSILS}

The calcareous nannofossil assemblages of the Trubi Formation were reported by ScIUTo et al. (2018). The presence of Ceratholithus acutus GARTNER \& BUKRY, 1974, and that of Reticulofenestra zancleana Di Stefano \& StURIALE, 2010, allow the Trubi Formation, to be assigned to one of the basal Zanclean calcareous nannofossil biozones, CNPL1 Zone sensu BACKMAN et al. (2012) or MNN 12 Biozone sensu MARTINI (1971). The nannofossil assemblages of Abbeveratoio and Villafranca Tirrena section are similar, and are rich with the specimens being well preserved. The presence of Ceratolithus acutus and Reticulofenestra zancleana in basal samples (LI 1-3) of Abbeveratoio indicate basal biozone MNN12 (early Pliocene, Zanclean). In particular, the presence of $R$. zancleana defines partial-range subzone MNN $12 \mathrm{~b}$ with the first occurrence (FO) into the Cycle 1 (5,332 Ma) and the last common occurrence (LCO) at Cycle $7(5,199 \mathrm{Ma})$, as reported by DI Stefano \& Sturiale (2010). In addition, few specimens of Amaurolithus primus are found in the same samples. Samples LI 4 and LI 5 show a decrease in the abundance of reticulofenestrids and an increase in Coccolithus pelagicus. The species Helicosphaera carterii becomes frequent from sample LI 5 to the top of the section. In Villafranca Tirrena the calcareous nannofossil assemblages are rich throughout the section, though Ceratolithus acutus and Reticulofenestra zancleana are rare, and Scyphosphaera apsteinii and Scyphosphaera piriformis are rare but well preserved. Helicosphaera carterii is common.

\section{Discussion}

Among the ostracod species found in the sections under study, Agrenocythere pliocenica (SEGUENZA, 1880) is particularly significant because, according to BENSON (1972a, 1972b, 1973, 1984), it indicates psychrospheric oceanic conditions, i.e., water masses generally deeper than $1000 \mathrm{~m}$ with temperature around $4^{\circ}-8^{\circ} \mathrm{C}$ (BENSON, 1973). The $A$. pliocenica $\mathrm{FO}$ in the Mediterranean Basin corresponds to the first common occurrence (FCO) of Globorotalia margaritae (COLALONGO et al., 1990), and is reported from all Pliocene deepwater sediments in central and southern Italy (e.g., Sciuto, 2003, 2014a) and from the bathyal Pliocene sequences in ODP cores from the Tyrrhenian Sea (BENSON, 1972a, 1972b; Colalongo \& PASINI, 1980; Colalongo et al., 1990). Agrenocythere pliocenica became extinct in the Mediterranean during the Calabrian because of the raising of the Gibraltar threshold that prevented the entry of Atlantic cold water into the Mediterranean, thus forcing the disappearance of the psychrosphere (BENSON, 1973).

The distribution of Bythocypris obtusata and $B$. antoniettae ScIUTO, 2012, seems to have been influenced by temperature. $B$. obtusata has been reported from the modern Norwegian and British 
coasts in water depths between 145 and $165 \mathrm{~m}$ by SARS (1928) and in the Recent Mediterranean Sea at depths between 150 and $2905 \mathrm{~m}$ by PURI et al. (1969). B. antoniettae was found by BREMAN (1975) in an interval of core 353 from bathyal sediments of the Adriatic Sea, corresponding, according to STRAATEN (1966), to a very cold period of the early Pleistocene. As fossils, the species are reported from upper Pliocene-Pleistocene deep-water environments (ScIUTO, 2003, 2012, 2014a, 2015). Their occurence at Abbeveratoio indicates that the two species were present in the Mediterranean basin during the Zanclean Stage.

Costa (Cuneocosta) tricostata pliocenica is commonly referred to Pliocene and Pleistocene bathyal environments (RUgGieRI, 1992; ScIUTO, 2005, 2014a).

Cytherella spp. and Bairdia conformis are relatively abundant and, while showing very broad bathymetric distributions in both the Atlantic and the Mediterranean (BONADUCE et al., 1983; WHATLEY \& Coles, 1987; GueRnet \& LeTHIERS, 1989; MONTENEGRO et al., 1998), are represented in most bathyal associations (BENSON, 1973; ScIUTO, 2003, 2014a, 2014b).

Acanthocythereis colinii ScIUTo, 2014b, is reported from Pliocene bathyal sediments from Capo Milazzo (ScIUTo, 2014a, 2014b). Its occurrence at Abbeveratoio demonstrates its presence in the Mediterranean basin, in the Zanclean Stage.

Poorly represented species such as Ruggieria tetraptera palpebralis RUGGIERI, 1960, Buntonia dertonensis RUGGIERI, 1954, and B. sublatissima (NEVIANI, 1906) are reported from deep-water sediments (e.g., ScIUTO, 2003), with B. sublatissima also known in the Recent in shallower environments.

The group of Krithe species, considered heurybates but normally present in ostracod associations of bathyal environments (e.g., Coles et al., 1996; ScIUTO, 2003, 2014a, 2014b, 2015), is strongly represented at Villafranca, where Krithe compressa reaches significant values of abundance (Table I).This latter species is synonymous with Krithe sp. 5 of WHATLEY and ZHAO (1993) which has been found living below $900 \mathrm{~m}$ in the South China Sea (Bonaduce \& BARRA, 2002).

Finally, Oblitacythereis mediterranea BENSON, 1977, is known in the Pliocene of Mediterranean region, from the Atlantic coast of Morocco to $\mathrm{Cy}$ prus and in cores from the eastern Mediterranean (DSDP Site 376), as well as in outcrop, especially in northern Sicily (BENSON, 1977). The genus Oblitacythereis ranges from the Paleogene to the Recent and typically lives in the lower thermosphere just above the psychrosphere (BENSON, 1977). This genus and its association with a typical deep-water assemblage, define a sedimentation depth of about 500-700 m situated above the boundary between the psychrosphere and the overlying thermosphere in the Miocene Ras il-Pellegrin section (BONADUCE \& BARRA, 2002).
On the basis of synecological and autoecological data, all species recorded here, can be considered compatible with each other and referable in full to a very deep water environment since the basal samples in all the section.

The foraminiferal data informs an understanding of both the structure of the water column and the conditions of the sea floor in two different palaeogeographical contexts, the Villafranca Tirrena Basin in the north and the northwestern border of the Hyblean Plateau in the south.

The distribution and frequencies of planktonic species (Table I), including those belonging to the warm-water oligotrophic genera Globigerinoides and Orbulina, demonstrates a well organised marine water column. Indeed, Globigerinoides obliquus, G. sacculifer and G. ruber, common at Abbeveratoio and very abundant at Villafranca Tirrena, evidences that warm, shallow oligotrophic waters are always present and stable into the water column. The genus Orbulina, ever-present and very abundant in both sections, indicates the occurrence of persistent warm and highly productive intermediate waters. The proliferation of neogloboquadrinids, which are phytoplankton grazers that live close to or just below the thermocline, testifies to the presence of a deep chlorophyll zone.

In both sections, the occurrences, sometimes very abundant, of the cold-water eutrophic Globigerina bulloides group, together with Turborotalita quinqueloba, suggests that the water column was thermally stratified. This thermal signal is more evident at Villafranca Tirrena where T. quinqueloba is abundant; in contrast, this species is absent from Abbeveratoio.

Sphaeroidinellopsis spp., which characterise the basal Zanclean (e.g., Couvering et al., 2000; VIOLANTI et al., 2011) with its acme zones, occur very rarely in the basal samples of both sections, and then disappear.

The most important events identified in the two sections studied are (Fig. 2):

1. the AE (acme end) of Sphaeroidinellopsis in sample 6 from the VT section and sample 3 from Abbeveratoio. At Villafranca Tirrena, the first occurrence of small forms of Globorotalia margaritae (identified as G. margaritae primitiva) coincides with the $A E$.

2. the first peak of dextral Neogloboquadrina acostaensis in sample 1 and the second peak in sample 5 from Abbeveratoio;

3. the FCO of Globorotalia margaritae in sample 10 at Villafranca Tirrena and in sample 5 at Abbeveratoio section, and

4. two peaks of sinistral Neogloboquadrina acostaensis in samples 12 and 13 at Villafranca Tirrena. 
Benthic assemblages provide valuable information about depth and oxygen content and availability of nutrients at the sea floor. The infaunal and shallow-infaunal forms are represented by a rather high number of taxa that, sometimes, are characterised by low relative abundances. The dominant species in all the assemblages are Siphonina reticulata, Bulimina aculeata, $B$. marginata, Uvigerina peregrina and $U$. pigmaea.

The abundance of Siphonina reticulata, inferred to be indicative of Early Pliocene Mediterranean Intermediate Water (EPMIW) (SGARRELLA et al., 1997), suggests that this synchronous re-coIonisation event reported from throughout the Mediterranean (SPEZZAFERRI et al., 1998; IACCARINo et al., 1999; PIERRE et al., 2006; RouCHY et al., 2007; VIOLANTI et al., 2011) is recognisable in our sections also and can be correlated with lithological cycle 6 (Di Stefano et al., 1996).

The epifaunal assemblages in the two sections (including Cibicides, Cibicidoides, Fontbotia, Gyroidinella, Heterolepa, Lenticulina, Planularia, Planulina, and Pyrgo) are comparable. The abundance of each species is generally very low, with only Cibicidoides pseudoungerianus, Lenticulina orbicularis, L. calcar, Planulina ariminensis, Gyroidina altiformis showing rather high values.

The prevalence in the assemblages of infaunal and epifaunal species that preferred cold bottom waters, such as Lenticulina orbicularis, Planulina ariminensis and Siphonina reticulata, demonstrates that the sea floor was consistently cold. The constant presence of the epifaunal Planulina ariminensis, characteristic of well-oxygenated conditions (KouvenHoven \& ZWAN, 2006), and the cooccurrence of the passive suspension feeder Cibicidoides pseudoungerianus (JORISSEN, 1988; MURRAY, 1991, 2006), widespread on well-oxygenated bottoms with high organic-carbon fluxes, indicate that the seafloor did not experience a decrease in oxygen level and that nutrients were always abundant. The availability of nutrients is supported also by the constant presence, in both sections, of the epifaunal and detritivore Lenticulina orbicularis. The presence of common to abundant infaunal species Bulimina aculeata, B. marginata, Uvigerina peregrina and $U$. pigmaea in the uppermost three samples at Abbeveratoio implies an increase in organic matter on the seafloor and at the water-sediment interface. The above-mentioned species, however, are generally rare at Villafranca Tirrena and become more abundant only in samples VT 9 (where they are frequent) and VT 11 (common). The increase in organic matter in this peculiar interval is evidenced also by the common occurrence in sample VT 11 of the infaunal species Marginulinopsis costata that proliferates on soft bottoms enriched in organic matter (BALDANZA et al., 2018). This species is common to abundant in the uppermost three samples at Abbeveratoio.

Abundant organic matter in bottom sediment, which is essential for infaunal species, is limited to discrete intervals of the two sections: at Villafranca Tirrena, from the samples VT9 to VT11, and at Abbeveratoio from samples LI 3 to LI 7.

As indicated by SgARRELLA et al. (2012), the species Planulina ariminensis, Cibicidoides spp. and Hoeglundina elegans preferred oligotrophic and oxic seafloor conditions while the spinose $B u$ limina and costate Uvigerina favoured eutrophic or meso-eutrophic and hypoxic or oxic bottom conditions.

The bathymetric depth is indicated, in both sections, by the abundant and constant presence of outer neritic to bathyal species (Bulimina aculeata and B. marginata, Cibicidoides pseudoungerianus, Uvigerina peregrina and U. pigmaea, Hoeglundina elegans, Planulina ariminensis, Gyroidina altiformis, Lenticulina orbicularis, L. calcar, Melonis padanum, and Siphonina reticulata).

According to SGARRELLA et al. (2012), the species Lenticulina orbicularis, Planulina ariminensis and Siphonina reticulata indicate cold, oxygenated and/or oligotrophic bathyal environments at a depth of 200-600 metres whereas Planulina ariminensis was recognised by DRINIA et al. (2010) as occurring at an upper bathyal depth.

DRINIA et al. (2010) inferred open-marine conditions for the Messinian/early Pliocene transition in the eastern Mediterranean (Zakynthos Island, Greece) from the diversity of benthic and planktonic foraminifers. Again, according to Pujos, 1976, and JORISSEN, 1988, the abundance of Lenticulina spp., Cibicidoides pseudoungerianus, Planulina ariminensis, Pullenia and Gyroidina and the absence of shelf-taxa suggest an upper bathyal depth.

\section{Conclusion}

The new data provided by ostracods and benthic foraminifers allow us to reconstruct the palaeoenvironmental conditions that existed during the deposition of the lowermost Trubi Formation, above the M/P boundary.

A well-organised water column, with stable warm shallow oligotrophic waters followed by highly productive intermediate warm waters with a deep chlorophyll zone in which phytoplankton grazers (neogloboquadrinids) proliferated, developed during lower Trubi sedimentation.

The presence in both sections of cold-water eutrophic species shows thermal stratification of the water column. The bottom was constantly cold, probably with little mixing of water masses and isolation of the seabed. Food availability, in the form of nutrients and organic fluxes which stimulated the proliferation of benthic infaunal/ shallow infaunal and epifaunal species, was generally high.

The coexistence of Agrenocythere pliocenica and Oblitacythereis mediterranea in the upper middle part of the Abbeveratoio section evidences the existence, at the bottom of the palaeobasin, of oceanic conditions corresponding to the transition between the psychrosphere and the thermo- 
sphere at a depth of around 500-700 m (BonADUCE \& BARRA, 2002). At Villafranca Tirrena, the presence of Agrenocythere pliocenica, a psychrospheric species that lived under oceanic conditions deeper than $1000 \mathrm{~m}$ and at $4^{\circ}-8^{\circ} \mathrm{C}$ (BENSON, $1973,1978)$, confirms the greater depth and decidedly colder conditions at the bottom of the Villafranca basin compared to the Licodia Eubea ba$\sin$.

No reworking of fossils has been detected in any samples. Taxa referable to environments shallower than the bathyal zone are absent so that all species identified and, hence, all fossil assemblages can be considered in situ.

In the sections studied and in equivalent stratigraphic successions elsewhere in the region, the Trubi Formation conformably overlies either the upper Messinian Lago-Mare facies or the Messinian evaporitic facies with a sharp boundary. In outcrop there is no evidence of erosion at the boundary. This observation accords with conclusions drawn from most stratigraphic sections containing the Messinian/Zanclean boundary (e.g. CITA \& RYAN, 1973; CITA et al., 1978).

The character of the boundary, together with the absence of faunal contamination since the basal samples, as already reported by BENSON (1973), suggests an undisturbed environment since the beginning of sedimentation.

The conformable relationship at the MessinianPliocene transition in Sicily is distinctly different from the relationship occurring in other sectors of the Mediterranean basin, particularly in the Western Mediterranean near the Straits of Gibraltar (Alboran Sea, Malaga basin) where the Messinian/Zanclean boundary is marked by a strongly erosional surface at the top of the Miocene (GARCia-CAstellanos et al., 2009; Guerra-MercháN et al., 2010; CARUSo et al., 2020). The Miocene deposits on both sides of the straits, are deeply incised, with the erosional channels filled by Pliocene and post-Pliocene sediments. Incision was effected by a catastrophic flood event, generated by an enormous volume of Atlantic water that, following the sudden lowering of the Gibraltar threshold by subsidence or erosion, refilled the Mediterranean basin (GARCIA-CASTELLANOS et al. 2009; GUERRA-MERCHÁn et al., 2010).

In the Sicilian sections of the Trubi Formation studied, there is no mixing of marine and nonmarine faunas in the lower stratigraphic levels. No deposits related to Lago/Mare environments have been found above the Messinian/Zanclean boundary, in contrast to a report (GENNARI et al., 2008) from the northern Apennine region where a slow rise of oceanic water is interpreted with the development of environments intermediate between those of Lago-Mare and the oceanic ones above the Messinian/Zanclean Boundary. We deem it probable that these intermediate facies, given their rarity in the Messinian-Zanclean transition, may be due to local sedimentary displacement phenomena and redeposition rather than normal sedimentation. According several authors (e.g., CITA \& RYAN, 1973; CITA et al., 1978; Rouchy et al., 2001), it is logical to hypothesise, on the basis of the acquired data that, also in the studied sector, there has been a very rapid ingression of the Atlantic water following Messinian deposition. This process has resulted in a clear faunal and sedimentological differentiation between the upper Messinian and Zanclean facies.

The absence of erosional surfaces that characterises the Miocene/Pliocene boundary in the western Mediterranean basin is probably due to the distance of the studied sections from the Atlantic-Mediterranean seaway. The energy of the Zanclean flow that caused the erosion of both sides of the Straits of Gibraltar (GARCIA-CASTELLANos et al., 2009) dissipated as the water mass flowed eastward due to its lateral and vertical expansion. The subsequent impingement upon the Sicilian threshold would have led to a further loss of energy as the of the western basin filled.

\section{Acknowledgments}

The authors are grateful to the reviewers and the editors for detailed comments on the manuscript. A special thank to Stephen CAREY for the precious suggestions and comments on the English language. Thanks are due also to Mr. Alfio VIOLA (Electronic Microscopy Laboratory, University of Catania) for assistance with SEM photomicrographs. Catania Palaeoecological Research Group contribution no. 449. Research carried out with funds intended for ScIUTO, provided by the University of Catania "Piano per la Ricerca 20162018" to A. Rosso, n. 22722132118.

\section{Bibliographic references}

Abate S., Barra D., Aiello G. \& Bonaduce G. (1993).- The genus Krithe BRADY, CROSSKEY and ROBERTSON, 1874 (Crustacea: Ostracoda) in the Pliocene-Early Pleistocene of the M. San Nicola section (Gela, Sicily).- Bollettino della Società Paleontologica Italiana, Modena, vol. 32, no. 3, p. 349-366.

Agalarova D.A., Kadyrova Z.K. \& KulijeVA S.A. (1961).- Ostracoda from Pliocene and post Pliocene deposits of Azerbaijan, Baku.- Azerbaijan State Publisher, Baku, 420 p. [in Russian].

BACKMAN J., RAFFi I., Rio D., Fornaciari E. \& PÄLIKE H. (2012).- Biozonation and biochronology of Miocene through Pleistocene calcareous nannofossils from low and middle latitudes.Newsletters on Stratigraphy, Stuttgart, vol. 45, no. 3, p. 221-244.

Baldanza A., Bizzarri R., Famiani F., Garassino A., Pasini G., Cherin M. \& Rosatini F. (2018).- The early Pleistocene whale-fall community of Bargiano (Umbria, Central Italy): Paleoecological insights from benthic foraminifera and brachyuran crabs.- Palaeontologia Electronica 21. 1.11A 1-27. URL: https://doi.org/10.26879/ 779 
Barra D., Bonaduce G. \& Sgarrella F. (1998).Paleoenvironrnental bottom water conditions in the early Zanclean of the Capo Rossello area (Agrigento, Sicily).- Bollettino della Società Paleontologica Italiana, vol. 37 no. 1, p. 61-88.

BENSON R.H. (1972a).- Ostracodes as indicators of threshold depth in the Mediterranean during the Pliocene. In: StAnLeY D.J. (ed.), The Mediterranean Sea: a natural sedimentation laboratory.- Dowden, Hutchinson \& Ross, Stroudsburg, p. 63-73.

BENSON R.H. (1972b).- The Bradleya problem, with descriptions of two new psychrospheric ostracode genera, Agrenocythere and Poseidonamicus (Ostracoda: Crustacea).- Smithsonian Contributions to Paleobiology, Washington D.C., vol.12, p. 1-138.

BENSON R.H. (1973).- 36.2 Psychrospheric and continental Ostracoda from ancient sediments in the floor of the Mediterranean.- In : RYAN W.B.F., HSU K.J, CITA M.B., DUMITRICA P., LORT J.M., Maync W., Nesteroff W.D., Pautot G., StRAdNeR H. \& Weze F.C.- Initial Reports of the Deep Sea Drilling Project, Washington D.C., vol. XIII, part 1, p. 1002-1008.

BENSON R.H. (1975).- The origin of the psychrosphere as recorded in changes of deep-sea ostracode assemblages.- Lethaia, Oslo, vol. 8 , p. 69-83.

BENSON R.H. (1977).- Evolution of Oblitacythereis from Paleocosta (Ostracoda: Trachyleberididae) during the Cenozoic in the Mediterranean and Atlantic.- Smithsonian Contributions to Palaeobiology, Washington D.C., vol. 33, p. 147.

BENSON R.H. (1978).- 35. The paleoecology of the ostracodes of DSDP Leg 42A. In: Hsü K.J., Montadert L., Bernoulli D., Bizon G., Cita M., ERICKSON A., FABRICIUS F., GARRISON R.E.,. KIDD R.B., MÉlières F., Müller C. \& WRight R.C.Initial Reports of the Deep Sea Drilling Project, Washington D.C., vol. XLII, part 1, p. 777786.

BENSON R.H. (1984).- Estimating greater paleodepths with ostracodes, especially in past thermospheric oceans.- Paleogeography, Paleoclimatology, Paleoecology, vol. 48, p. 107141.

Bold W.A. van den (1946).- Contribution to the study of Ostracoda with special reference to the Tertiary and Cretaceous microfauna of the Carribbean Region.- Ph.D. Rijksuniversiteit te Utrecht, J.H. de Bussy, Amsterdam, 167 p.

BONADUCE G. \& BARRA D. (2002).- The ostracods in the palaeoenvironmental interpretation of the late Langhian - early Serravallian section of Ras-il-Pellegrin (Malta).- Rivista Italiana di Paleontologia e Stratigrafia, Milano, vol. 108, p. 211-222.
Bonaduce G., Barra, D. \& Aiello G. (1999).- The genus Henryhowella PURI, 1957 (Crustacea, Ostracoda) in the Atlantic and Mediterranean from Miocene to Recent.- Bollettino della Società Paleontologica Italiana, Modena, vol. 38, p. 59-72.

Bonaduce G., Ciliberto B., Masoli M., Minichelli G. \& Pugliese N. (1983).- The deep-water benthic ostracodes of the Mediterranean. In: MADDOCKS R.F. (ed.), Application of Ostracoda.University of Houston, p. 459-471.

Bonaduce G. \& SgarRelLa F. (1999).- Paleoecological interpretation of the latest Messinian sediments from southern Sicily (Italy).- Memorie della Società Geologica Italiana, Roma, vol. 54 , p. 83-91.

BRADY G.S. (1866).- On new or imperfectly known species of marine Ostracoda.- Transactions of the Zoological Society of London, London, vol. 5, p. 956-993.

BREMAN E. (1975).- Ostracodes in a bottom core from the deep southeastern basin of the Adriatic Sea. I, II.- Koninklijke Nederlandse Akademie van Wetenschappen, Proceedings (Ser. B), Amsterdam, vol. 78, p. 198-218.

BRocchi G. V. (1814).- Conchiologia fossile subappennina, con osservazioni sugli Appennini e sul suolo adiacente.- Dalla Stamperia Reale, Milano, pp. 214.

Caruso A., Blanc-Valleron M.-M., Da Prato S., Pierre C. \& Rouchy J.-M. (2020).- The late Messinian"Lago-Mare" event and the Zanclean Reflooding in the Mediterranean Sea: New insights from the Cuevas del Almanzora section (Vera Basin, South-Eastern Spain).- EarthScience Reviews, vol. 200, article 102993, 20 p.

ChANNell J.E.T., Rio D. \& Thunell R.C. (1988).Miocene/Pliocene boundary magnetostratigraphy at Capo Spartivento, Calabria, Italy.- Geology, vol. 16, no. 12, p. 1096-1099.

Cipollari P., Cosentino D., Radeff G., Taylor F., SCHILDGEN T.F., FARANDA C., GROSSI F., GliOZZI E., Smedile A., Gennari R., Darbas G., DudAs F. Ö., GÜRBÜZ K., NAZIK A. \& EChTLER H. (2013).Easternmost Mediterranean evidence of the Zanclean flooding event and subsequent surface uplift : Adana Basin, southern Turkey. In : ROBERTSON A. H.F., PARLAK O. \& ÜNLÜGENÇ U.C. (eds.), Geological Development of Anatolia and the Easternmost Mediterranean Region.- Geological Society, London, Special Publications, vol. 372, p. 473-493.

CITA M. (1973).- 47. Pliocene biostratigraphy and chronostratigraphy. In: RYAN W.B.F., HsU K.J, CitA M.B., DUMitrica P., LORT J.M., MAYNC W., Nesteroff W.D., Pautot G., Stradner H. \& Weze F.C. - Initial Reports of the Deep Sea Drilling Project, Washington D.C., vol. XIII, part 1, p. 1343-1379. 
CITA M. (1975).- Foraminiferal biozonation of Pliocene deep-sea sediments from the Mediterranean. A revision.- Rivista Italiana di Paleontologia e Stratigrafia, Milano, vol. 81, p. 527-566.

CitA M.B. \& GARTNER S. (1973).- The Stratotype Zanclean: foraminiferal and nannofossil biostratigraphy.- Rivista Italiana di Paleontologia e Stratigrafia, Milano, vol. 79, p. 503-558.

CitA M.B. \& RYAN W.B.F. (1973).- 47.5 Time-scale and general synthesis. In: RYAN W.B.F., HSU K.J, Cita M.B., Dumitrica P., LORT J.M., MAYNC W., Nesteroff W.D., Pautot G., Stradner H. \& WeZE F.C.- Initial Reports of the Deep Sea Drilling Project, Washington D.C., vol. XIII, part 1, p. 1405-1415.

Cita M.B., Santambrogio S., Melillo B. \& Rogate F. (1990).- 14. Messinian paleoenvironments: New evidence from the Tyrrhenian Sea (ODP Leg 107). In: Kastens K. A., MAscle J., AurouX C., Bonatti E., Broglia C., Channell J., Curzi P., Emeis K.-C., Glaçon G., Hasegawa S., Hieke W., McCoy F., McKenzie J., Mascle G., MendelSON J., Muller C., Rehault J.-P., Robertson A., SARTORI R., Sprovieri R. \& TORII M.- Proceedings of the Ocean Drilling Program, Scientific Results, Washington D.C., vol. 107, p. 14051415.

CitA M.B., WRight R.C., RYAN W.B.F. \& LONGinelli A. (1978).- 53. Messinian paleoenvironments. In : Hsü K.J., Montadert L., Bernoulli D., BIzON G., CitA M., ERICKSON A., FABricius F., GARRISON R.E.,. Kidd R.B., MÉlières F., MülleR C. \& WRIGHT R.C.- Initial Reports of the Deep Sea Drilling Project, Washington D.C., vol. XLII, part 1, p. 1003-1035.

ColAlongo M.L. \& PASINI G. (1980).- 30. La ostracofauna plio-pleistocenica della sezione della Vrica in Calabria (con considerazioni sul limite Neogene-Quaternario).- Bollettino della Società Paleontologica Italiana, Modena, vol. 19, no. 1, p. 44-126.

Colalongo M.L., Pasini G., Poluzzi A. \& Sprovieri R. (1990).- Relationship between the benthic foraminifers and the ostracodes in the Pliocene-Pleistocene Tyrrhenian deep-sea record (ODP LEG 107, site 654). In: KASTENS K. A., Mascle J., Auroux C., Bonatti E., Broglia C., Channell J., Curzi P., Emeis K.-C., Glaçon G., Hasegawa S., Hieke W., McCoy F., McKenzie J., Mascle G., Mendelson J., Muller C., Rehault J.P., Robertson A., Sartori R., Sprovieri R. \& TORII M.- Proceedings of the Ocean Drilling Program, Scientific Results, Washington D.C., vol. 107, p. 479-493.

Coles G.P., Ainsworth N.R., Whatley R.C. \& JONES R.W. (1996).- Foraminifera and Ostracoda from Quaternary carbonate mounds associated with gas seepage in the Porcupine Basin, offshore western Ireland.- Revista Española de Micropaleontologia, Madrid, vol. 28, no. 2, p. 113-151.
CostA O.G. (1853).- Paleontologia del Regno di Napoli. Parte III.- Giorgio Franz, Monaco, 196 p. (XVI Pls.).

Couvering J. A. van, CAStradori D., CitA M.B., FREDERIK J. H. \& Rio D. (2000).- The base of the Zanclean Stage and of the Pliocene Series.- Episodes, Beijing, vol. 23, no. 3, p. 179187.

Decima A. (1964).- Ostracodi del gen. Cyprideis JONES del Neogene e del Quaternario italiani.Palaeontographia Italica, vol. 57, p. 81-133.

Di Geronimo I., Esu D. \& Grasso M. (1989).- Gli strati a"congerie" del Messiniano superiore del margine nord occidentale ibleo. Caratteristiche faunistiche e possibili implicazioni paleogeografiche e paleoclimatiche.- Atti Accademia Peloritana dei Pericolanti, Messina, vol. 68, no. 1, p. 129-150.

Di Stefano E., Sprovieri R. \& Scarantino $S$. (1996).- Chronology of biostratigraphic events at the base of the Pliocene.- Paleopelagos, Roma, vol. 6, p. 401-414.

Di Stefano A. \& Sturiale G. (2010).- Refinements of calcareous biostratigraphy at the Miocene/ Pliocene Boundary in the Medi terranean region.- Geobios, Villeurbanne, vol. 43, p. 5-20.

Drinia H., ANTONARAKou A., TSOUROU T., TZORTZAKI E., Filippidi A. \& Nikolaou K. (2010).- The Messinian/early Pliocene transition in eastern Mediterranean: New palaeoenvironmental data from the Kalamaki section (Zakynthos Island, Greece)-. Geophysical Research Abstracts, Vol. 12, EGU2010-13926-1, EGU General Assembly 2010.

Garcia-Castellanos D., Estrada F., JimÉnez-Munt I., Gorini C., Fernàndez M., Vergés J. \& De VICENTE R. (2009).- Catastrophic flood of the Mediterranean after the Messinian salinity crisis.Nature, vol. 462, p. 778-782.

GARTNER S. \& BUKRY D. (1974).- Ceratolithus acutus GARTNER and BUKRY n. sp. and Ceratolithus amplificus BUKRY and PERCIVAL - nomenclatural clarification.- Tulane Studies in Geology and Paeontology, vol. 11, p. 115-118.

Gennari R., Iaccarino M.S., Di Stefano A., StuRiale G., Cipollari P., Manzi V., Roveri M. \& Cosentino D. (2008).- The Messinian-Zanclean boundary in the Northern Apennine.- Stratigraphy, vol. 5, no. 3-4, p. 307-322.

Gliozzi E., Ceci M.E., Grossi F. \& Ligios S. (2007).- Paratethyan ostracod immigrants in Italy during late Miocene.- Geobios, Villeurbanne, vol. 40, p. 325-337.

Grossi F., Gliozzi E. \& Cosentino D. (2011).- Paratethyan ostracod immigrants mark the biostratigraphy of the Messinian Salinity Crisis.Joannea Geologie and Paläontologie, Graz, vol. 11 , p. 66-68. 
Grossi F., Gliozzi E., Anadónc P., Castorina F. \& VoltAGgIO M. (2015).- Is Cyprideis agrigentina DECIMA a good paleosalinometer for the Messinian Salinity Crisis? Morphometrical and geochemical analyses from the Eraclea Minoa section (Sicily).- Palæogeography, Palæoclimatology, Palæoecolology, vol. 419, p. 75-89.

GUERNET C. \& LethieRs F. (1989).- Ostracodes et recherche des milieux anciens : possibilités et limites.- Bulletin de la société Géologique de France, Paris, vol. 8, no. 5, p. 577-588.

Guerra-Merchán A., Serrano F., Garcés M., Gofas S., ESU D., Gliozzi E. \& GRossi F. (2010).Messinian Lago-Mare deposits near the Strait of Gibraltar (Malaga Basin, S Spain).- Palæogeography, Palæoclimatology, Palæoecology, vol. 285, p. 264-276.

Hasegawa S., Sprovieri R. \& Poluzzi A. (1990).29. Quantitative analysis of benthic foraminiferal assemblages from Plio-Pleistocene sequences in the Tyrrhenian Sea, ODP Leg 107. In: Kastens K. A., Mascle J., Auroux C., Bonatti E., Broglia C., Channell J., Curzi P., Emeis K.-C., Glaçon G., Hasegawa S., Hieke W., McCoy F., MCKenzie J., Mascle G., Mendelson J., Muller C., Rehault J.-P., Robertson A., Sartori R., Sprovieri R. \& TORII M.- Proceedings of the Ocean Drilling Program, Scientific Results, Washington D.C., vol. 107, p. 461-478.

Hsü K.J., RYAN W.F.B. \& CitA M.B. (1973).- Late Miocene desiccation of the Mediterranean.Nature, UK, vol. 242, p. 240-244.

Iaccarino S., Castradori D., Cita M.B., Di Stefano E., Gaboardi S., McKenzie J.A., Spezzaferri S. \& SPROVIERI R. (1999).- The Miocene/Pliocene boundary and the significance of the earliest Pliocene flooding in the Mediterranean.- Memorie della Società Geologica Italiana, vol. 54, p.109-131.

JORISSEN F.J. (1988).- Benthic foraminifera from the Adriatic Sea: principles of phenotypic variation.- Utrecht Micropaleontological Bulletins, Utrecht, vol. 37, p.1-174.

KOUVENHOVEN T.J. \& ZWAN G.J. van der (2006).- A reconstruction of late Miocene Mediterranean circulation patterns using benthic foraminifera.- Palæogeography, Palæoclimatology, Palæoecology, vol. 230, no. 1-4, p. 373-385.

Krijgsman W., Hilgen F.J., Raffi I., Sierro F.J. \& WILSON D.S. (1999).- Chronology, causes and progression of the Messinian Salinity Crisis.Nature, vol. 400 , p. 652-655.

Krijgsman W., Capella W., Simon D., Hilgen F.J., Kouwenhoven T.J., MeiJer, P.T. \& Flecker R. (2018).- The Gibraltar Corridor: Watergate of the Messinian Salinity Crisis.- Marine Geology, vol. 403, 238-246.

Lancis C., Tent-Manclús J.E., Flores J.A. \& Soria J.M. (2015).- The Pliocene Mediterranean infilling of the Messinian Erosional Surface: New biostratigraphic data based on calcareous nannofossils (Bajo Segura Basin, SE Spain).- Geo- logica Acta, Barcelona, vol. 13, no. 3, p. 211228.

LANGereis C.G. \& Hilgen F.J. (1991).- The Rossello composite: a Mediterranean and global reference section for the early to early late Pliocene.- Earth and Planetary Science Letters, vol. 104, p. 211-225.

LeNTINI F., GRASSO M. \& CARBone S. (1987).- Introduzione alla geologia della Sicilia e guida all'escursione.- Convegno della Società Geologica Italiana, Naxos-Pergusa 22-25 Aprile 1987, Catania, 60 p.

LIVENTAL V.E. (1929).- Ostracoda from the Akchagyl and Apscheron strata along the Babazansk section. In: AgaLAROVA D.A., KADYROVA Z.K. \& KULIEVA S.A. (eds., 1961), Ostracoda from Pliocene and post-Pliocene deposits of Azerbaijan.- Baku, 58 p. [in Russian].

MARTINI E. (1971).- Standard Tertiary and Quaternary calcareous nannoplankton zonation. In : FARINACCI A. (ed.), Proceedings of the II Planktonic Conference.- Tecnoscienza, Roma, vol. 2, p. 739-785.

MÉHES G. (1908).- Beitrage zur Kenntnis der pliozanen Ostrakoden Ungarns. II. Die Darwinulidaeen und Cytheridaeen der unterpannonischen Stufe.- Foldtani Kozlony, vol. 38, Supplement, p. 601-635.

Montenegro M.E., Pugliese N. \& Bonaduce G. (1998).- Shelf ostracods distribution in the Italian seas. In: Crasquin-SoleaU S., BRACCINI E. \& Lethiers F. (eds.), What about Ostracoda!- Bulletin du Centre Recherche elf Exploration Production, Pau, Mémoire 20, p. 91-101.

MOtTURA A. (1871).- Sulla formazione terziaria della zona solfifera della Sicilia.- Memorie descrittive della Carta Geologica d'Italia, Roma, vol. 1, p. 50-140.

MURRAY J. (2006).- Ecology and applications of benthic Foraminifera.- Cambridge University Press, p. 1- 426.

Neviani A. (1906).- Ostracodi delle sabbie postplioceniche di Carrubbare (Calabria).- Bollettino della Società Geologica Italiana, Roma, vol. 25 , p. $185-216$.

Ogniben L. (1957).- Petrografia della serie solfifera siciliana e considerazioni geologiche relative.- Memorie descrittive della Carta Geologica d'Italia, Roma, vol. 33, 276 p.

Orszag-Sperber F., Rouchy J.-M. \& BLANC-VALLERon M.-M. (2000).- La transition Messinien Pliocène en Méditerranée orientale (Chypre) : la période du Lago-Mare et sa signification.- Comptes Rendus de I'Académie des Sciences (Series IIA - Earth and Planetary Science), Paris, vol. 331, no. 7, p. 483-490.

Pedley M. \& Grasso M. (1992).- Miocene syntectonic sedimentation along the western margins of the Hyblean-Malta platform: A guide to plate margin processes in the central Mediterranean.- Journal of Geodynamics, vol. 15, p. 19-37. 
Pierre C., Caruso A., Blanc-Valleron M., Rouchy J.-M. \& OrzSAG-Sperber F. (2006).- Reconstruction of the paleoenvironmental changes around the Miocene-Pliocene boundary along a west-east transect across the Mediterranean.Sedimentary Geology, vol. 188-189, p. 319340.

Pujos M. (1976).- Écologie des foraminifères benthiques et des Thécamoebiens de la Gironde et du plateau continental Sud-Gascogne: application á la connaissance du Quaternaire terminal de la région Ouest-Gironde.- Mémoires de I'Institut de Géologie du Bassin d'Aquitaine, Bordeaux, vol. 8, $274 \mathrm{p}$.

Puri H.S., Bonaduce G. \& Gervasio A.M. (1969).Distribution of Ostracoda in the Mediterranean. In: NeALE J.W. (ed.), The taxonomy, morphology and ecology of recent Ostracoda.Oliver \& Boyd, Edinburgh, p. 358-411.

Rouchy J.-M. \& CARUso A. (2006).- The Messinian salinity crisis in the Mediterranean Basin: a reassessment of the data and an integrated scenario.- Sedimentary Geology, vol. 188-189, p. 35-67.

Rouchy J.-M., Caruso A., Pierre C., BlancVALLERON M.-M. \& BASSETTI M.A. (2007).- The end of the Messinian salinity crisis: evidences from the Chelif Basin (Algeria).- Palæogeography, Palæoclimatology, Palæoecology, vol. 254, p. 386-417.

Rouchy J.-M., Orszag- Sperber F., Blanc-Valleron M.-M., Pierre C., Rivière M., Combourieu-NeBOUT N. \& PANAYIDES I. (2001).- Paleoenvironmental changes at the Messinian-Pliocene boundary in the eastern Mediterranean: southern Cyprus basins.- Sedimentary Geology, vol. 145, p. 93-117.

Roveri M., Flecker R., Krijgsman W., LOFi J., LugLi, S., Manzi V., Sierro J.F., Bertini A., Camerlenghi A., De lange G., Govers R., Hilgen F. J., Hübscher C., Meijer T. P. \& Stoica M. (2014).The Messinian Salinity Crisis: Past and future of a great challenge for marine sciences.- Marine Geology, vol. 352, p. 25-58

Roveri M., Manzi V., Gennari R., Iaccarino S. \& LUGLI S. (2008).- Recent advances in the Messinian stratigraphy of Italy and their Mediterranean-scale implication.- Bollettino della Società Paleontologica Italiana, Modena, vol. 47, p. 71-85.

RugGieRI G. (1953).- Età e fauna di un terrazzo marino sulla costa Ionica della Calabria.- Giornale di Geologia (serie 2), Bologna, vol. 23, p. 19-168,

RUGGIERI G. (1954).- Iconografia degli Ostracodi marini del Pliocene e del Pleistocene italiani.Atti della Società Italiana di Scienze Naturali, Milano, vol. 93 , no. 3, 4, p. 561-575.

RUgGieri G. (1960).-- Ostracofauna miocenica del ragusano.- Rivista mineraria siciliana, Palermo, vol. 63 , p. 1-5.
Ruggieri G. (1967).- The Miocene and later evolution of the Mediterranean Sea. In: ADAMS C.G. \& AGER D.V. (eds.), Aspects of Tethyan biogeography.- Systematics Association, University of California, Publication 7, p. 283- 290.

RUGGIERI G. (1992).- Considerazioni tassonomiche su ostracodi neogenici e pleistocenici risultate dalla revisione di vecchi lavori dello scrivente.Bollettino della Società Paleontologica Italiana, Modena, vol. 31, no. 2, p. 175-188.

SARS G.O. (1866).- Oversightog Norges marine Ostracoder.- Forhandlinger $i$ videnskabs selskabet i Christiania, 1865, p. 1-130.

SARS G.O. (1922-1928).- An account of the Crustacea of Norway vol. IX: Ostracoda.- Bergen Museum, $277 \mathrm{p}$.

ScIUTO F. (2003).- Dati preliminari sull' ostracofauna pliocenica di Capo Milazzo (Sicilia NE).Bollettino della Società Paleontologica Italiana, Modena, vol. 42, no. 1-2, p. 179-184.

ScIUTo F. (2005).- Ostracodi batiali pleistocenici di Capo Milazzo (Sicilia NE) ed implicazioni paleoambientali.- Rendiconti della Società Paleontolologica Italiana, Modena, vol. 2, p. 219227.

Sciuto F. (2012).- New ostracod species from Lower Pleistocene bathyal sediments of Capo Milazzo (NE, Sicily).- Bollettino della Società Paleontologica Italiana, Modena, vol. 51, no. 2, p. 117-125.

Sciuto F. (2014a).- Ostracods of the upper Pliocene-Pleistocene Punta Mazza succession (NE Sicily) with special focus on the Family Trachileberididae Silvester-BRADLEY, 1948, and description of a new species.- Carnets Geol., Madrid, vol. 14, no. 1, p. 1-13 19.

ScIUTo F. (2014b).- Acanthocythereis colinii nomen novum for $A$. reticulata ScIUTO, 2014.Carnets Geol., Madrid, vol. 14, no. 3, p. 39.

Sciuto F. (2015).- Palaeoenviromental and palaeogeographical traits on deep-water ostracod assemblages from the lower Pleistocene sediments along the Ionian side of Mount Etna (Sicily, Italy).- Carnets Geol., Madrid, vol. 15, no. 14, p. 179-197.

Sciuto F., Baldanza A., Temani R. \& Privitera G. (2018).- New reports of Paratethyan ostracods affinity from the Mediterranean Basin (Sicily, Italy).- Palaeontologia Electronica, 21.1.12A, 19 p. URL: https://doi.org/10.26879/800

SeguenzA G. (1880).- Le formazioni terziarie nella provincia di Reggio Calabria.- Regia Accademia dei Lincei, Roma, vol. 3, 416 p.

Sgarrella F., Di Donato V. \& Sprovieri R. (2012).Benthic foraminiferal assemblage turnover during intensification of the Northern Hemisphere glaciation in the Piacenzian Punta Piccola section (southern Italy).- Palæogeography, Palæoclimatology, Palæoecology, vol. 333334 , p. $59-74$ 
Sgarrella F., Sprovieri R., Di Stefano E., Caruso A. (1997).- Palaeoceanographic conditions at the base of the Pliocene in the southern Mediterranean basin.- Rivista Italiana di Paleontologia e Stratigrafia, vol. 103, p. 207-220.

SISSINGH W. (1972).- Late Cenozoic Ostracoda in the South Aegean Island Arc.- Utrecht Micropaleontogy Bulletin, vol. 6, p. 1-187.

Spezzaferri S., CitA M.B. \& MCKenzie J.A. (1998).2. The Miocene/Pliocene boundary in the eastern Mediterranean: results from sites 967 and 969. In: ROBERTSON A.H.F., EMEIS K.-C., Richter C., CAmerlenghi A. (eds.).- Proceedings of the Ocean Drilling Program, Scientific Results, Washington D.C., vol. 160, p. 9-28.

Sprovieri R. \& Hasegawa S. (1990).- 28. PlioPleistocene benthic foraminifer stratigraphic distribution in the deep-sea record of the Tyrrhenian Sea (ODP Leg 107). In: KASTENS K. A., Mascle J., Auroux C., Bonatti E., Broglia C., Channell J., Curzi P., Emeis K.-C., Glaçon G., Hasegawa S., Hieke W., McCoy F., McKenzie J., Mascle G., Mendelson J., Muller C., Rehault J.P., Robertson A., Sartori R., Sprovieri R. \& TORII M.- Proceedings of the Ocean Drilling Program, Scientific Results, Washington D.C., vol. 107 , p. 429-459.

STRAATEN L.M.J.U. van (1966).- Micro-malacological investigation of cores from the southeastern Adriatic Sea.- Koninklijke Neder-landse Akademie van Wetenschappen, Verhandelingen (series B), Amsterdam, vol. 69, p. 429445.

Temani R., Ammar K.H. \& Sciuto F. (2018).- New reports of Messinian Lago-Mare Episodes from Tunisia: ostracods and paleoenvironmental implications In: ZHANG Z., KHÉLIFI N., MeZGHANI
A. \& HEGGY E. (eds.),Patterns and mechanisms of climate, paleoclimate and paleoenvironmental changes from low-latitude regions.- Proceedings of the 1st Springer Conference of the Arabian Journal of Geosciences (CAJG-1), Tunisia 2018, p. 69-71.

TERQUEM O. (1878).- Les foraminifères et les entomostracès-ostracodes du Pliocène supérieur de I'Ile de Rhodes. Deuxième Section (ostracodes).- Mémoires de la Société Géologique de France, vol. 3, p. 81-135.

TRENKWAlder S., Violanti D., Atri A. d', LozAR F., Dela Pierre F. \& Irace A. (2008).- The Miocene/Pliocene boundary and the early Pliocene micropalaeontological record: new data from the Tertiary Piedmont Basin (Moncucco quarry, Torino Hill, northwestern Italy).- Bollettino della Società Paleontologica Italiana, vol. 47 (2), p. 87-103.

Violanti D., Dela Pierre F., Trenkwalder S., Lozar F., Clari P., Irace A. \& Atri A. d' (2011).- Biostratigraphic and palaeoenvironmental analyses of the Messinian/Zanclean boundary and Zanclean succession in the Moncucco quarry (Piedmont, northwestern Italy). Bulletin de la Société Géologique de France, vol. 182, no. 2, p. 149-162.

Whatley R. \& Coles G. (1987).- The late Miocene to Quaternary ostracoda of leg 94, Deep Sea Drilling Project.- Revista Española de Micropaleontologia, Madrid, vol. 19, no. 1, p. 33-97.

WhATLEY R. \& ZHAO Q.H. (1993).- The Krithe problem: A history of the distribution of Krithe and Pararakrithe (Crustacea, Ostracoda) in the South China Sea.- Palæogeography, Palæoclimatology, Palæoecolology, vol. 103, p. 281297. 


\section{Plates}

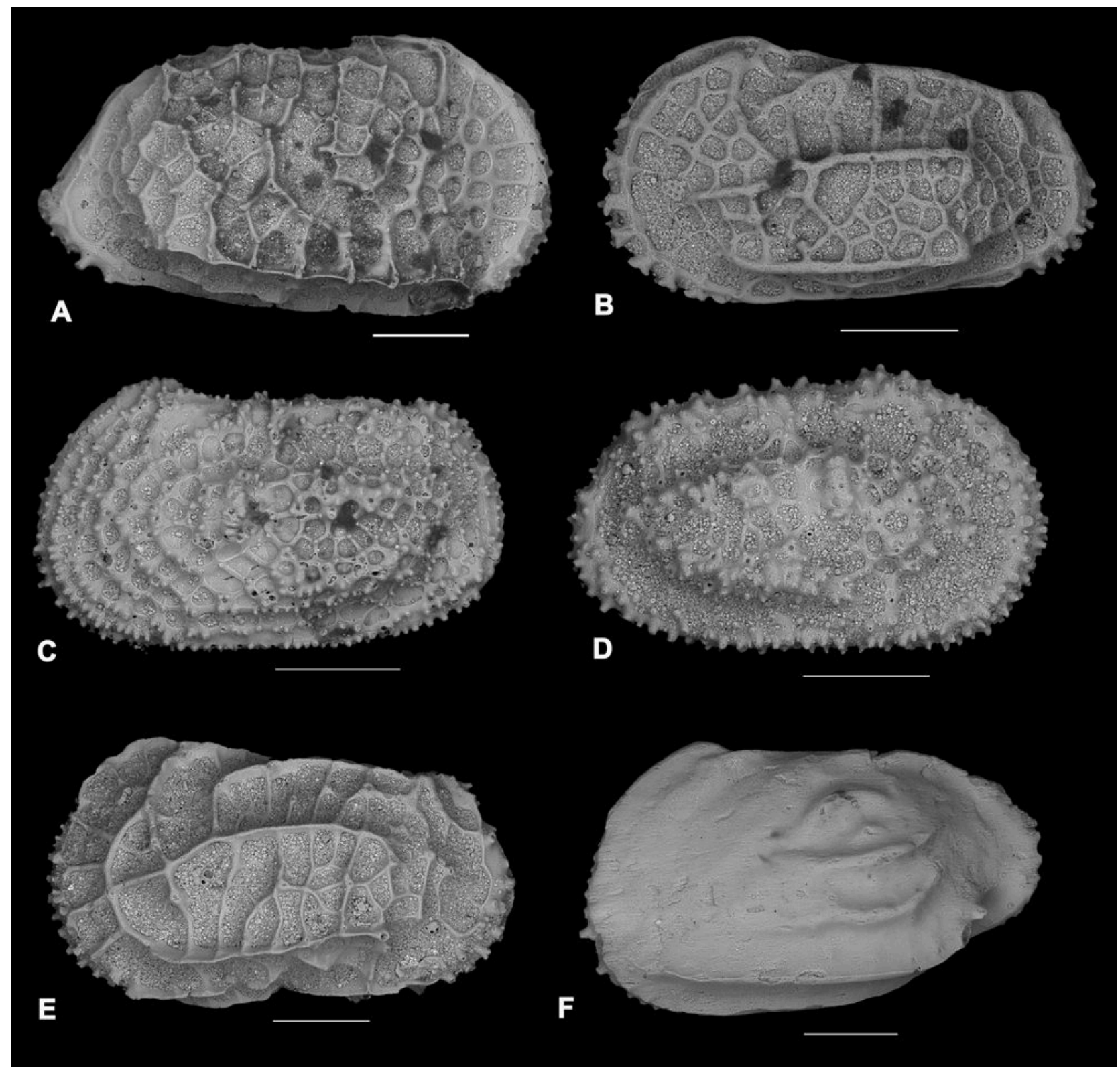

Plate 1: Ostracods (scale bar: $200 \mu \mathrm{m}$ ).

A) Agrenocythere pliocenica (SeguenzA, 1880); right valve, external lateral view.

B) Costa (Cuneocosta) tricostata pliocenica RUGGIERI, 1992; left valve, external lateral view.

C) Henryhowella ex H. hirta (COSTA, 1853) group, SCIUTO, 2014; left valve, external lateral view.

D) Henryhowella ex $H$. profunda BONADUCE et al., 1999 group, SCIUTO, 2014; right valve, external lateral view.

E) Oblitacythereis mediterranea BENSON, 1977; left valve, external lateral view.

F) Ruggieria tetraptera palpebralis RUGGIERI, 1960; left valve, external lateral view. 


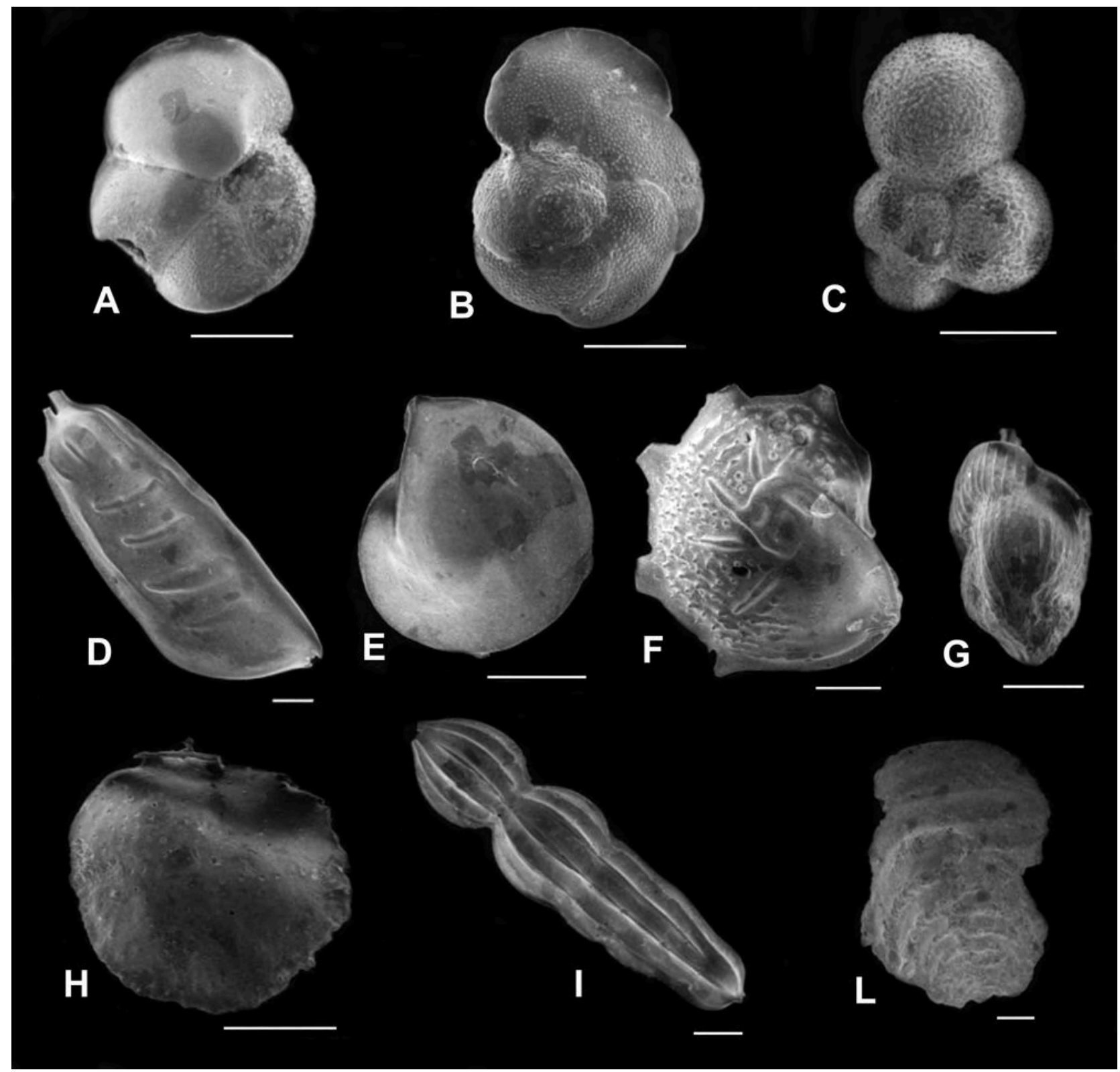

Plate 2: Foraminifers (scale bar: $200 \mu \mathrm{m}$ ).

A) Globorotalia margaritae BOLLI \& BERMUDEZ, 1965; apertural view.

B) Globorotalia margaritae evoluta CITA, 1973; spiral view.

C) Globigerina bulloides (ORBIGNY, 1826); spiral view.

D) Vaginulina legumen (LiNNAEUS, 1758).

E) Lenticulina orbicularis (ORBIGNY, 1826).

F) Lenticulina calcar (LINNAEUS, 1758) with features like to the Lenticulina echinata (ORBIGNY, 1846).

G) Uvigerina pygmaea (ORBIGNY, 1826)

H) Siphonina reticulata (CZJZEK, 1848).

I) Marginulina costata (BATSCH, 1791)

L) Vulvulina pennatula (BATSCH, 1791). 